\title{
A Colorimetric Immunosensor Based on Hemin@MI Nanozyme Composites, with Peroxidase-like Activity for Point-of-care Testing of Pathogenic E. coli O157:H7
}

\author{
Yan Leng, ${ }^{*}, * *$ Shengjun Bu, ${ }^{* *}$ Zhongyi LI, ${ }^{* *}$ Zhuo HAO, ${ }^{* *}$ Chengyou MA, ${ }^{* * *}$ Xiuxia He, ${ }^{* \dagger}$ and \\ Jiayu WAN**† \\ *School of Life Science and Technology, Changchun University of Science and Technology, Changchun 130022, \\ China \\ **Institute of Military Veterinary, Academy of Military Medical Sciences, Changchun 130122, China \\ ***College of Geo-Exploration Science and Technology, Jilin University, Changchun 130026, China
}

\begin{abstract}
Recently, nanozymes have become a topic of particular interest due to their high activity level, stability and biocompatibility. In this study, a visual, sensitive and selective point-of-care immunosensor was established to test the pathogen Escherichia coli O157:H7 (E. coli O157:H7). Hemin and magainin I (MI) hybrid nanocomposites (Hemin@MI) with peroxidase-mimicking activities were synthesized via a "one-pot" method, involving the simple mixing of an antimicrobial peptide (MI) against E. coli $\mathrm{O} 157: \mathrm{H} 7$ and hemin in a copper sulfate sodium phosphate saline buffer. Hemin@MI nanocomposites integrating target recognition and signal amplification were developed as signal probes for the point-ofcare colorimetric detection of pathogenic E. coli O157:H7. Hemin@MI nanocomposites exhibit excellent peroxidase activity for the chromogenic reaction of ABTS, which allows for the visual point-of-care testing of $E$. coli $\mathrm{O} 157: \mathrm{H} 7$ in the range of $10^{2}$ to $10^{8} \mathrm{CFU} / \mathrm{mL}$, with a limit of detection of $85 \mathrm{CFU} / \mathrm{mL}$. These data suggest this immunosensor provides accessible and portable assessments of pathogenic E. coli O157:H7 in real samples.
\end{abstract}

Keywords Hemin, nanozyme, nanocomposites, pathogenic E. coli O157:H7, point-of-care detection

(Received March 5, 2020; Accepted August 31, 2020; Advance Publication Released Online by J-STAGE September 4, 2020)

\section{Introduction}

Foodborne pathogenic bacteria, e.g., E. coli $\mathrm{O} 157: \mathrm{H} 7$, pose a threat to public health through many contamination sources, including water and food. E. coli $\mathrm{O} 157: \mathrm{H} 7$ is a well-known multi-host foodborne pathogen that causes gastrointestinal infectious. Worldwide, the pathogen causes more than two million acute cases every year. ${ }^{1}$ Hence, there is an urgent need to develop a sensitive and simple point-of-care method to detect this harmful pathogen, especially in underdeveloped areas of the world. Although traditional culture-based methods are still gold standards for testing for E. coli $\mathrm{O} 157: \mathrm{H} 7$, the process of enrichment, separation and culture is both time-consuming and laborious, potentially taking up to seven days. ${ }^{2}$ Similarly, while polymerase chain reaction (PCR) offers high sensitivity and efficiency, the approach requires a complex setup and expensive reagents and equipment. ${ }^{3}$ As these techniques are time consuming and expensive, there is a continued interest in developing sensitive and simple point-of-care detection methods. Of the many alternative strategies, colorimetric immunosensors are particularly advantageous, as they are visualized, easy to

Y. L. and S. B. contributed equally to this work.

$\dagger$ To whom correspondence should be addressed.

E-mail: chinese_hxx@yahoo.com.cn (X. H.); wanjiayu@hotmail. $\operatorname{com}($ J. W. $)$ operate and fast to read. ${ }^{4}$ Therefore, it is beneficial to explore new sensitive colorimetric immunosensor to meet the needs of early clinical point-of-care diagnosis, especially in underdeveloped regions. 5

A key feature of a colorimetric immunosensor is that it should have excellent labels as signal transduction amplifiers. In recent decades, more attention has been given to designing different kinds of natural enzyme labels. The co-immobilization of antibodies and natural enzymes is achieved through relatively complicated procedures, such as covalent cross-linking and encapsulation. Unfortunately, these methods reduce enzymatic activity. $^{6} \quad$ In addition, environmental conditions such as temperature, inhibitors, acidity and protease digestion can affect the catalytic activities of some natural enzymes, and the cost of producing and storing natural enzymes is often high. ${ }^{7,8}$ These limit the wider application of natural enzymes. In contrast, nanozymes are nanomaterials with bio-enzyme-like characteristics, and in recent years they have become highly topical in view of their high stability, low cost, and easy preservation and preparation. ${ }^{9}$ Therefore, it is important to develop and explore nanozymes that can replace natural enzymes in colorimetric immunoassay applications. ${ }^{10,11}$ However, the application of nanozymes for signal amplification in colorimetric immunosensors remains a major technical challenge. ${ }^{12}$

Hemin is a well-known natural metalloporphyrin that exhibits peroxidase-like catalytic activities. However, a serious drawback 
A

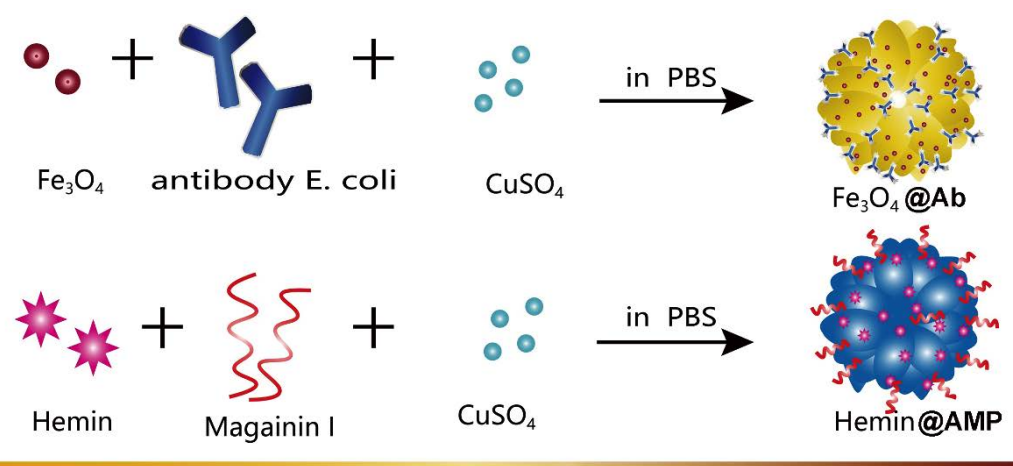

B

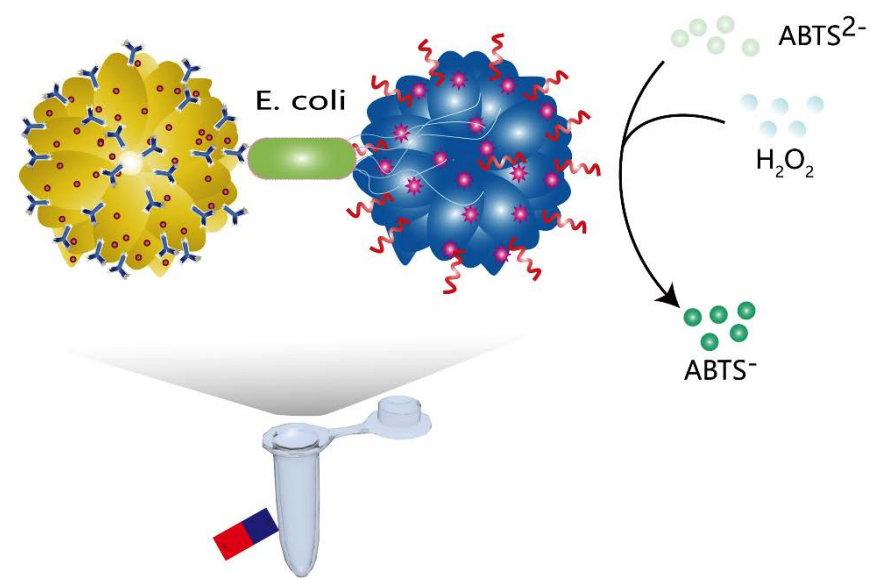

Scheme 1 (A) Synthesis of hemin@MI nanozyme composites and $\mathrm{Fe}_{3} \mathrm{O}_{4} @ \mathrm{Ab}$ magnetic nanocomposites. (B) The colorimetric immunosensor for the detection of E. coli $\mathrm{O} 157: \mathrm{H} 7$ based on hemin@MI nanozyme composites and $\mathrm{Fe}_{3} \mathrm{O}_{4} @ \mathrm{Ab}$ magnetic nanocomposites.

of hemin is its instability due to oxidative degradation. Therefore, much effort has been focused on ways to prevent hemin self-degradation. The immobilization of hemin molecules to support materials constitutes a logical and promising approach to preventing this self-degradation. A variety of materials have been exploited as solid supports, e.g., reduced graphene oxide, ${ }^{13}$ $\mathrm{g}_{-} \mathrm{C}_{3} \mathrm{~N}_{4}$ nanosheets, ${ }^{14}$ graphene, ${ }^{15} \quad \mathrm{MoS}_{2}$-Au-PEI layered nanocomposites, ${ }^{16}$ amino-modified single-walled carbon nanotube ${ }^{17}$ and metal-organic frameworks. ${ }^{18}$ The large surface areas of these supporting materials greatly improve the catalytic performance of hemin.

Recently, a new type of flower-like organic-inorganic nanocomposite has inspired interest due to its non-toxicity, ease of preparation, large surface area and high biocompatibility. ${ }^{19}$ The flower-like organic-inorganic nanocomposite exhibits enhanced activity, stability and reusability of organic components (e.g., antibodies, enzymes). ${ }^{20,21}$ The flower-like organicinorganic nanocomposites with large surface areas, have been used to immobilize a variety of nanoparticles as solid supports. ${ }^{22,23}$ Besides, peptides are also applied as an organic component to mediate the synthesis of the flower-like organicinorganic nanocomposites. ${ }^{24}$

In this work (Scheme 1), magainin I, a positively charged peptide that has broad-spectrum activity against E. coli O157:H7, and which has the strongest binding ability to E. coli O157:H7 compared to other bacteria, ${ }^{25}$ and copper phosphate were respectively used as organic and inorganic components to synthesize flower-like organic-inorganic nanocomposites. These were then exploited as supporting materials to immobilize hemin (hemin@MI). This “one-pot” method simply involved mixing magainin I and hemin in a copper sulfate sodium phosphate buffered saline (PBS solution). Antibody-modified magnetic microbeads are commonly used for the specific recognition and separation of detection targets in immunoassays. ${ }^{22}$ However, antibody-modified magnetic microbeads are expensive and require complex preparations. In order to prevent the occurrence of occupancy or competitive binding, we selected E. coli $\mathrm{O} 157: \mathrm{H} 7$ antibodies that specifically bind to E. coli O157:H7. The E. coli O157:H7 antibody binds to the O antigen on E. coli $\mathrm{O} 157: \mathrm{H} 7$ cells, so we synthesized E. coli $\mathrm{O} 157: \mathrm{H} 7$ antibody $(\mathrm{Ab})-\mathrm{Cu}_{3}\left(\mathrm{PO}_{4}\right)_{2}$ hybrid organic-inorganic nanocomposites, embedding $\mathrm{Fe}_{3} \mathrm{O}_{4}\left(\mathrm{Fe}_{3} \mathrm{O}_{4} @ \mathrm{Ab}\right)$ via the facile "one-pot" method as magnetic capture probes in the immunosensor. After $\mathrm{Fe}_{3} \mathrm{O}_{4} @$ Ab capture of $E$. coli $\mathrm{O} 157: \mathrm{H} 7$ in a sample and incubating with hemin@MI, a specific sandwich-type format: $\mathrm{Fe}_{3} \mathrm{O}_{4} @ \mathrm{Ab}-E$. coli O157:H7-hemin@MI, was formed. In the presence of an 2'-azino-bis(3-ethylbenzothiazoline-6-sulfonic acid) (ABTS) $/ \mathrm{H}_{2} \mathrm{O}_{2}$ substrate, high levels of colored oxidative products are produced by the hemin@MI catalyzed redox reaction. Based on the signal amplification of nanocomposites and magnetic separation of nanocomposites, this approach is highly efficient for the point-of-care detection of E. coli $\mathrm{O} 157: \mathrm{H} 7$.

\section{Experimental}

\section{Reagents}

2'-Azino-bis(3-ethylbenzothiazoline-6-sulfonic acid) (ABTS), dimethyl sulfoxide (DMSO), hemin and copper(II) sulfate pentahydrate $\left(\mathrm{CuSO}_{4} \cdot 5 \mathrm{H}_{2} \mathrm{O}\right)$ were purchased from Sigma- 
Aldrich (MO, USA). $\mathrm{H}_{2} \mathrm{O}_{2}$ was provided by Shanghai Ling Feng Chemical Regent Co. Ltd (Shanghai, China). The antimicrobial peptide magainin I (GIGKFLHSAGKFGKAFVGEIMKS) and $\mathrm{Fe}_{3} \mathrm{O}_{4}$ were obtained from Sangon Biotech Co. Ltd (Shanghai, China). The E. coli O157:H7 antibody (ab 252713) was purchased from Abcam (Hong Kong, China). Strains of Staphylococcus aureus (CICC 21600), Listeria monocytogenes (CICC 21529), Salmonella typhimurium (CICC 24119), E. coli O157:H7 (CICC 21530) and E. coli DH5a (CICC 10222) were obtained from the China Center for Type Culture Collection (Wuhan, China). The $\mathrm{pH}$ of the PBS solution was adjusted with $\mathrm{NaOH}$ and $\mathrm{HCl}$. The PBS buffer contained $10 \mathrm{mM} \mathrm{NaH} \mathrm{PO}_{4}$ and $10 \mathrm{mM} \mathrm{Na} \mathrm{HPO}_{4}, 137 \mathrm{mM} \mathrm{NaCl}$, and $2.7 \mathrm{mM} \mathrm{KCl}$. All analytical grade or higher reagents and solvents were used directly, without further purification.

\section{Synthesis of nanocomposites}

According to the "one-pot" method (18), hemin@MI and $\mathrm{Fe}_{3} \mathrm{O}_{4} @ \mathrm{Ab}$ nanocomposites were prepared with some modifications. First, $40 \mu \mathrm{L}$ magainin $\mathrm{I}(1 \mathrm{mg} / \mathrm{mL})$ and $20 \mu \mathrm{L}$ $\mathrm{CuSO}_{4}(120 \mathrm{mM})$ were diluted to $1 \mathrm{~mL}$ in PBS solution ( $\mathrm{pH} 7.4$, $10 \mathrm{mM})$. Hemin (4 mg/mL dissolved in DMSO) was then added with mild stirring, and followed by incubation at $25^{\circ} \mathrm{C}$ for $24 \mathrm{~h}$. Next, $10 \mu \mathrm{L}$ E. coli $\mathrm{O} 157: \mathrm{H} 7$ antibody $(1 \mathrm{mg} / \mathrm{mL})$ and $30 \mu \mathrm{L} \mathrm{CuSO}_{4}(120 \mathrm{mM})$ were diluted to $1 \mathrm{~mL}$ in PBS solution (pH 7.4, $10 \mathrm{mM}$ ) and then $25 \mu \mathrm{L} \mathrm{Fe}_{3} \mathrm{O}_{4}(40 \mathrm{mg} / \mathrm{mL})$ was added with mild stirring, followed by incubation at $25^{\circ} \mathrm{C}$ for $24 \mathrm{~h}$. The hemin@MI and $\mathrm{Fe}_{3} \mathrm{O}_{4} @ \mathrm{Ab}$ were obtained by centrifugation $(10000 \mathrm{rpm})$, rinsed twice in $0.1 \mathrm{mM}$ PBS (pH 7.4) and dispersed in PBS solution. The solution was stored at $4{ }^{\circ} \mathrm{C}$ for further use. The structure of hemin@MI and $\mathrm{Fe}_{3} \mathrm{O}_{4} @ \mathrm{Ab}$ nanocomposites was determined by scanning electron microscopy (Hitachi SU8010, Tokyo, Japan). An X-ray powder diffraction analysis of hemin@MI and $\mathrm{Fe}_{3} \mathrm{O}_{4} @ \mathrm{Ab}$ nanocomposites was performed using an X-ray polycrystal diffractometer (XD6, Beijing, China).

Colorimetric immunosensor procedure for the detection of E. coli O157:H7

A $2 \mu \mathrm{L}$ aliquot of $\mathrm{Fe}_{3} \mathrm{O}_{4} @ \mathrm{Ab}$ was added to $50 \mu \mathrm{L}$ of different concentrations of E. coli O157:H7, followed by incubation at $35^{\circ} \mathrm{C}$ for $90 \mathrm{~min}$. The solution was magnetically separated by rinsing three times with $0.1 \mathrm{mM}$ PBS. An $8 \mu \mathrm{L}$ aliquot of hemin@MI was added to the remaining $\mathrm{Fe}_{3} \mathrm{O}_{4} @ \mathrm{Ab}-E$. coli $\mathrm{O} 157: \mathrm{H} 7$ and incubated for $30 \mathrm{~min}$ at $35^{\circ} \mathrm{C}$. The $\mathrm{Fe}_{3} \mathrm{O}_{4} @ \mathrm{Ab}-$ E. coli O157:H7 was then bound to the hemin@MI. Magnetic separation removed unbound hemin@MI after washing three times in PBS. As shown in Scheme 1, hemin@MI, $\mathrm{Fe}_{3} \mathrm{O}_{4} @ \mathrm{Ab}$ and the target E. coli $\mathrm{O} 157: \mathrm{H} 7$ formed an immune-sandwich complex. Finally, $10 \mu \mathrm{L}$ ABTS and $5 \mu \mathrm{L} \mathrm{H}_{2} \mathrm{O}_{2}$ were added and maintained at room temperature for $5 \mathrm{~min}$, and the absorbance $(414 \mathrm{~nm})$ was immediately measured using an ultraviolet spectrophotometer (Nano Drop ND-1000, Thermo Fisher Scientific, Waltham, MA, USA).

\section{Optimization of assay conditions}

Different volumes of hemin $(20,30,40,50,60$, and $70 \mu \mathrm{L}$ dissolved in DMSO to achieve $4 \mathrm{mg} / \mathrm{mL}$ ) and magainin I (10, $20,30,40$, and $50 \mu \mathrm{L}$ at $1 \mathrm{mg} / \mathrm{mL}$ ) were employed to synthesize hemin@MI nanocomposites. Different volumes of $\mathrm{Fe}_{3} \mathrm{O}_{4}(5,15$, 25,35 , and $45 \mu \mathrm{L}$ at $40 \mathrm{mg} / \mathrm{mL}$ ) and $E$. coli $\mathrm{O} 157: \mathrm{H} 7$ antibody $(10,20,30,40$, and $50 \mu \mathrm{L}$ at $1 \mathrm{mg} / \mathrm{mL})$ were used to synthesize $\mathrm{Fe}_{3} \mathrm{O}_{4} @ \mathrm{Ab}$ nanocomposites. The volume of hemin@MI nanocomposites $(2,4,6,8$, and $10 \mu \mathrm{L})$ was optimized. The optimum volumes of $\mathrm{Fe}_{3} \mathrm{O}_{4} @ \mathrm{Ab}$ nanocomposites (1, 2, 3, 4, and
$5 \mu \mathrm{L})$ were determined. In addition, different $\mathrm{pH}$ levels $(4.5-$ 9.5), reaction temperatures $\left(15-55^{\circ} \mathrm{C}\right)$, ABTS concentrations $(3-11 \mathrm{mM})$ and $\mathrm{H}_{2} \mathrm{O}_{2}$ concentrations $(5-70 \mathrm{mM})$ were optimized to select the optimal conditions for E. coli $\mathrm{O} 157: \mathrm{H} 7$ detection. To assess the sensitivity parameters of the colorimetric immunosensor, the experimental group $\left(1.0 \times 10^{8} \mathrm{CFU} / \mathrm{mL}\right.$ E. coli $\mathrm{O} 157: \mathrm{H} 7)$ and the control group $(0 \mathrm{CFU} / \mathrm{mL}$ E. coli O157:H7) were analyzed simultaneously.

\section{The detection of E. coli O157:H7 in milk}

To validate the reliability of the colorimetric immunosensor, sterile milk, purchased from a local supermarket, was spiked with E. coli O157:H7. Different concentrations of E. coli O157:H7 $\left(10^{3}, 10^{4}\right.$, and $\left.10^{5} \mathrm{CFU} / \mathrm{mL}\right)$ were generated by diluting E. coli $\mathrm{O} 157: \mathrm{H} 7$ in the milk. A conventional UV-Vis spectrometer was used to quantify the E. coli $\mathrm{O} 157: \mathrm{H} 7$ spikes in the sterile milk samples to calculate spike recoveries $(\%)$ on the calibration plot.

\section{Statistical analysis}

GraphPad Prism 5 was used to analyze all data which were expressed as the mean \pm standard deviation. To validate assay accuracy, we measured all parameters at least three times.

\section{Results and Discussion}

\section{Characterization of nanocomposites}

The size and morphology of the "as-synthesized" nanocomposites were characterized by using a scanning electron microscope. At low magnification (Fig. 1A), the hemin@MI nanocomposites contained uniform spherical structures. Further observations (Fig. 1A) showed that hemin@MI nanocomposites exhibited flower-like structures with particle sizes of approximately $10 \mu \mathrm{m}$. The $\mathrm{Fe}_{3} \mathrm{O}_{4} @ \mathrm{Ab}$ nanocomposites contained uniform dispersed spherical structures, with particle sizes of approximately $20 \mu \mathrm{m}$ (Fig. 1B). The porous structures of these nanocomposites had high specific surface areas. The $\mathrm{Fe}_{3} \mathrm{O}_{4} @ \mathrm{Ab}$ nanocomposites contained porous layered structures where the $\mathrm{Fe}_{3} \mathrm{O}_{4}$ nanoparticles were embedded. However, nanoparticles were not observed on porous layered structures of hemin@MI nanocomposites, mainly because hemin was not observed by scanning electron microscopy. X-ray diffraction analysis showed that peaks of the hemin@MI nanocomposites coincided with peaks of hemin and copper phosphate crystals (Fig. 1C). In addition, the intensity of the diffraction peaks formed from 20 to $25^{\circ}$ indicated the crystalline structure of hemin in the pure powder state, demonstrating that hemin molecules might possess the same molecular packing mode within hemin single crystals. After formation of hemin@MI, the hemin molecules were dispersed in hybrid nanocomposites and in the amorphous state. As is well known, the typical diffraction peaks will weaken or disappear when molecules are in the amorphous state. These results proved that hemin and copper phosphate were contained in the hemin@MI nanocomposites. X-ray diffraction analysis (Fig. 1D) showed that the peaks of $\mathrm{Fe}_{3} \mathrm{O}_{4} @ \mathrm{Ab}$ nanocomposites coincided with the peaks of $\mathrm{Fe}_{3} \mathrm{O}_{4}$ and copper phosphate, indicating the successful preparation of $\mathrm{Fe}_{3} \mathrm{O}_{4} @ \mathrm{Ab}$ nanocomposites.

\section{Optimum performance identification}

To observe optimal performance of the colorimetric immunosensor, detection conditions were optimized. Firstly, for preparation of the signal probes of the immunosensor, hemin@MI nanocomposites, different volumes of $1 \mathrm{mg} / \mathrm{mL}$ 
$\mathbf{A}$

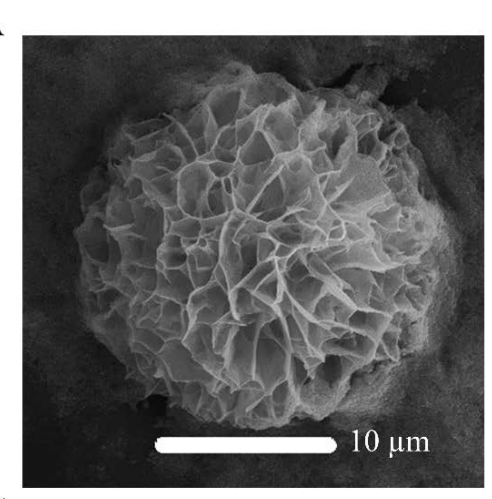

C

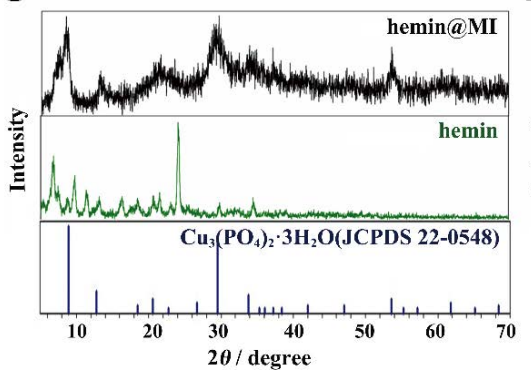

B

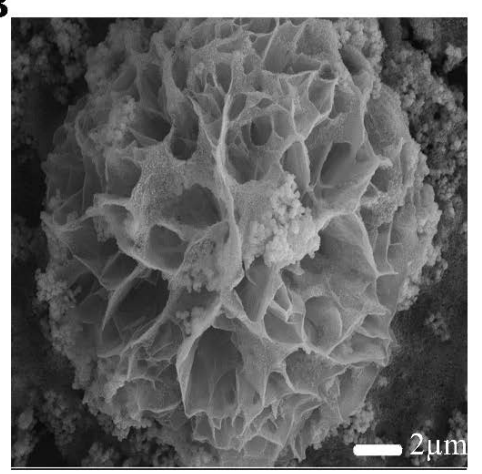

D

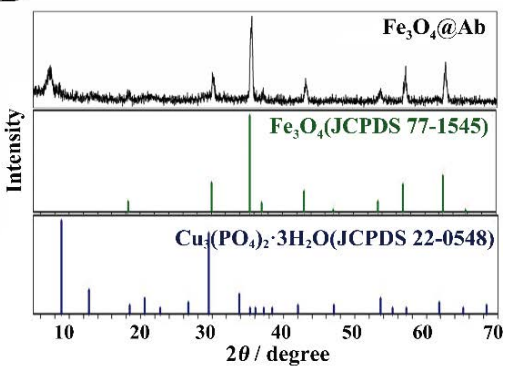

Fig. 1 (A) SEM image of hemin@MI nanocomposites. (B) SEM image of $\mathrm{Fe}_{3} \mathrm{O}_{4} @ \mathrm{Ab}$ nanocomposites. (C) XRD of hemin@MI nanocomposites (black line), hemin (green line), and copper phosphate (blue line). (D) XRD of $\mathrm{Fe}_{3} \mathrm{O}_{4} @ \mathrm{Ab}$ nanocomposites (black line), $\mathrm{Fe}_{3} \mathrm{O}_{4}$ (red line), and copper phosphate (blue line).

A

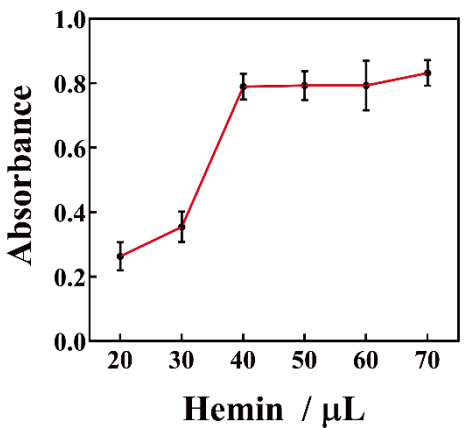

C

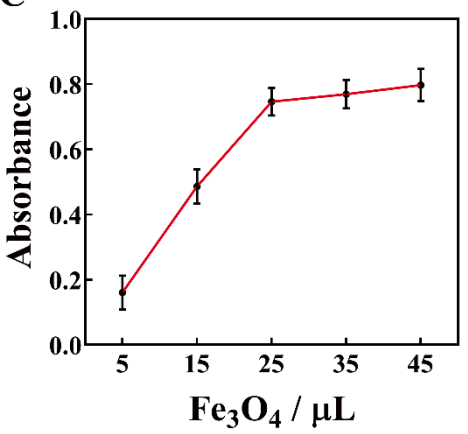

B

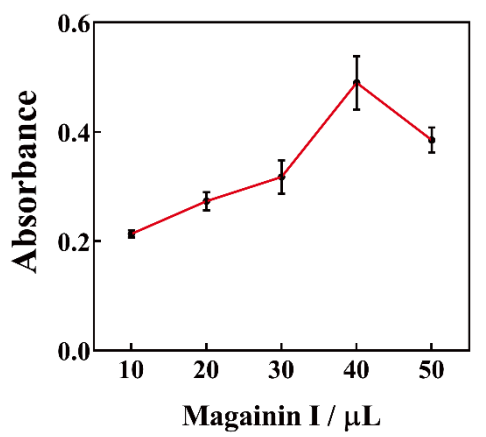

D

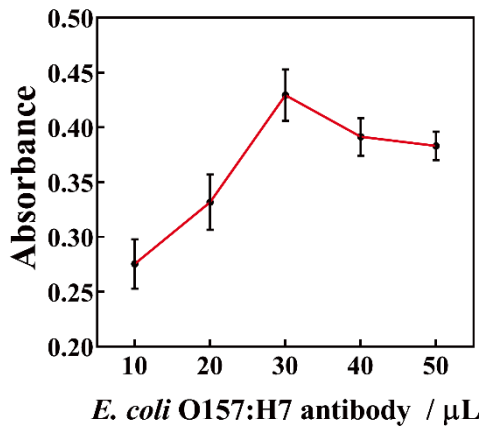

Fig. 2 Optimization of conditions for preparing nanocomposites with different volumes of (A) hemin (4 mg/mL) added to hemin@MI, (B) magainin I (1 mg/mL) added to hemin@ MI, (C) $\mathrm{Fe}_{3} \mathrm{O}_{4}$ (40 mg/ $\mathrm{mL}$ ) added to $\mathrm{Fe}_{3} \mathrm{O}_{4} @ \mathrm{Ab}$, and (D) E. coli $\mathrm{O} 157: \mathrm{H} 7$ antibody $(1 \mathrm{mg} / \mathrm{mL})$ added to $\mathrm{Fe}_{3} \mathrm{O}_{4} @ \mathrm{Ab}$. Absorbance changes are at $414 \mathrm{~nm}$, and the error bars were derived from three parallel experiments. 
when the hemin volume reached $40 \mu \mathrm{L}$. Therefore, $40 \mu \mathrm{L}$ hemin was chosen to prepare hemin@MI nanocomposites. As shown in Fig. 2B, ABTS absorbance increased with increasing magainin I volumes, and the signal intensity had decreased when the magainin I volume reached $40 \mu \mathrm{L}$. Therefore, $40 \mu \mathrm{L}$ magainin I was selected to prepare hemin@MI. The performance of this approach was also strongly affected by capture probe $\mathrm{Fe}_{3} \mathrm{O}_{4} @ \mathrm{Ab}$ nanocomposites. The volumes of $40 \mathrm{mg} / \mathrm{mL} \mathrm{Fe} \mathrm{O}_{4}$ $(5,15,25,35$, and $45 \mu \mathrm{L})$ and $1 \mathrm{mg} / \mathrm{mL}$ E. coli $\mathrm{O} 157: \mathrm{H} 7$ antibody $(10,20,30,40$, and $50 \mu \mathrm{L})$ for the preparation of $\mathrm{Fe}_{3} \mathrm{O}_{4} @ \mathrm{Ab}$ nanocomposites were also optimized (Figs. 2C and 2D). ABTS absorbance increased with increasing volumes of $\mathrm{Fe}_{3} \mathrm{O}_{4}$, and the signal intensity had not significantly increased when the hemin volume reached $25 \mu \mathrm{L}$. Therefore, $25 \mu \mathrm{L}$ $\mathrm{Fe}_{3} \mathrm{O}_{4}$ was chosen to prepare $\mathrm{Fe}_{3} \mathrm{O}_{4} @ \mathrm{Ab}$ nanocomposites. The ABTS absorbance exhibited the highest signal when the $E$. coli O157:H7 antibody volume was $30 \mu \mathrm{L}$. Thus, $30 \mu \mathrm{L}$ of $E$. coli O157:H7 antibody was selected for the preparation of $\mathrm{Fe}_{3} \mathrm{O}_{4} @$ Ab nanocomposites.

For the immunosensor, different volumes of hemin@MI $(2,4$, 6, 8, and $10 \mu \mathrm{L})$ and $\mathrm{Fe}_{3} \mathrm{O}_{4} @ \mathrm{Ab}(1,2,3,4$, and $5 \mu \mathrm{L})$ were analyzed. As shown in Figs. 3A and 3B, the colorimetric signal intensity decreased when the hemin@MI and $\mathrm{Fe}_{3} \mathrm{O}_{4} @ \mathrm{Ab}$ volumes reached $8 \mu \mathrm{L}\left(I / I^{\circ}\right.$, in which $I^{\circ}$ represent the absorbance of ABTS in a volume of different HNPs (hemin nanocomposite, hemin@MI) added under aseptic conditions, and I represents the absorbance of ABTS in a volume of different HNPs added under bacteriostatic conditions.) and $2 \mu \mathrm{L}$, respectively. Hence, $8 \mu \mathrm{L}$ hemin@MI and $2 \mu \mathrm{L} \mathrm{Fe}_{3} \mathrm{O}_{4} @ \mathrm{Ab}$ nanocomposite were selected for the following experiments. Furthermore, the effects of ABTS, $\mathrm{H}_{2} \mathrm{O}_{2}$ concentrations, incubation temperatures and $\mathrm{pH}$ level were also investigated. As shown in Fig. 4A, the signal increased with an increase in ABTS and when ABTS exceeded $10 \mathrm{mM}$ a signal plateau appeared. Thus, $10 \mathrm{mM}$ ABTS was used in the following experiments. The effects of different $\mathrm{H}_{2} \mathrm{O}_{2}$ concentrations were studied in the range 5 to $70 \mathrm{mM}$ (Fig. 4B). The colorimetric signal was highest at $30 \mathrm{mM} \mathrm{H}_{2} \mathrm{O}_{2}$. As shown in Figs. 4C and 4D, the highest colorimetric signal was obtained at $\mathrm{pH} 8.0$ and $35^{\circ} \mathrm{C}$. At $55^{\circ} \mathrm{C}$, the absorbance of ABTS is reduced, which is related to excessive temperature, enzyme inactivation or heat resistance. When the $\mathrm{pH}$ is 9.5 , the absorbance of ABTS is reduced. This is because hemin will be inactivated when it encounters strong alkali. Therefore, if the $\mathrm{pH}$ of the washing solution is too alkaline, the hemin activity will be reduced, and it will not be completely oxidized to produce colored products. Therefore, $35^{\circ} \mathrm{C}$ and $\mathrm{pH} 8.0$ were chosen as the optimal conditions for the reaction.

\section{Sensitivity}

To assess the performance of the colorimetric immunosensor,
A

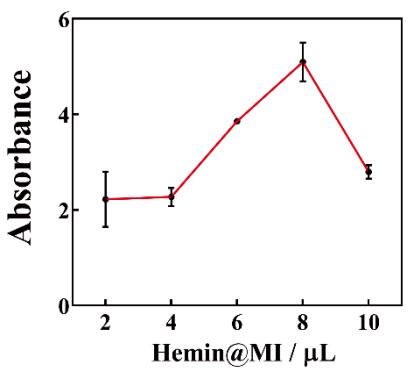

B

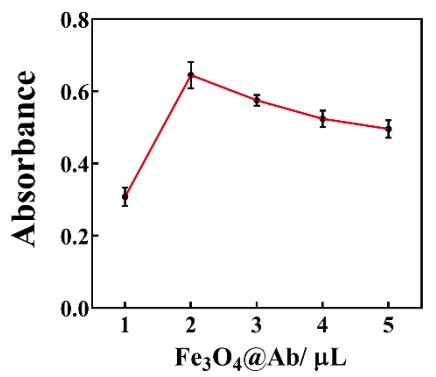

Fig. 3 Detection of $E$. coli $\mathrm{O} 157: \mathrm{H} 7$ using different volumes of (A) hemin@MI nanocomposites and (B) $\mathrm{Fe}_{3} \mathrm{O}_{4} @ \mathrm{Ab}$ nanocomposites. Absorbance changes are at $414 \mathrm{~nm}$, and the error bars were derived from three parallel experiments.

\section{A}

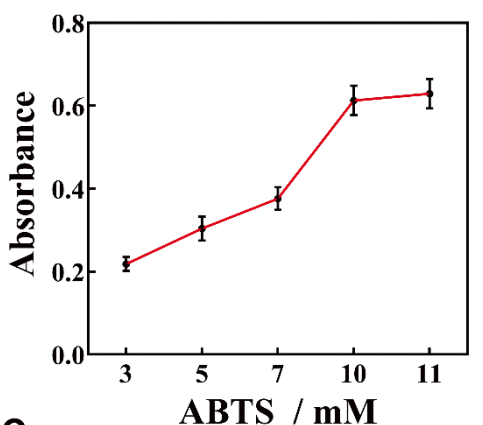

C

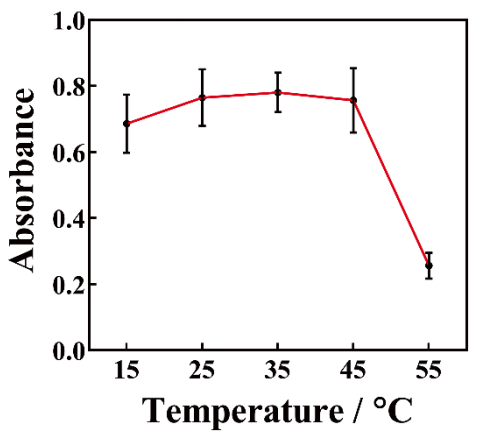

B

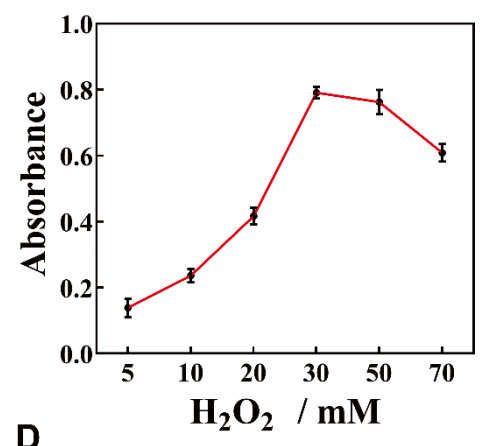

D

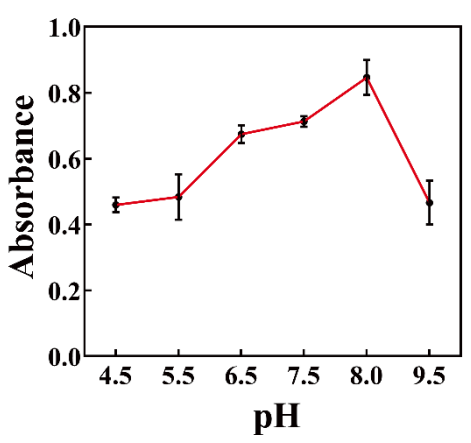

Fig. 4 Detection of $E$. coli $\mathrm{O} 157: \mathrm{H} 7$ with different (A) concentrations of $\mathrm{ABTS} \mathrm{H}_{2} \mathrm{O}_{2}, 30 \mathrm{mM}$, (B) amounts of $\mathrm{H}_{2} \mathrm{O}_{2}$ ABTS, $10 \mathrm{mM}$, (C) incubation temperatures and (D) washing buffer $\mathrm{pH}$. Absorbance changes are at $414 \mathrm{~nm}$, and the error bars were derived from three parallel experiments. 


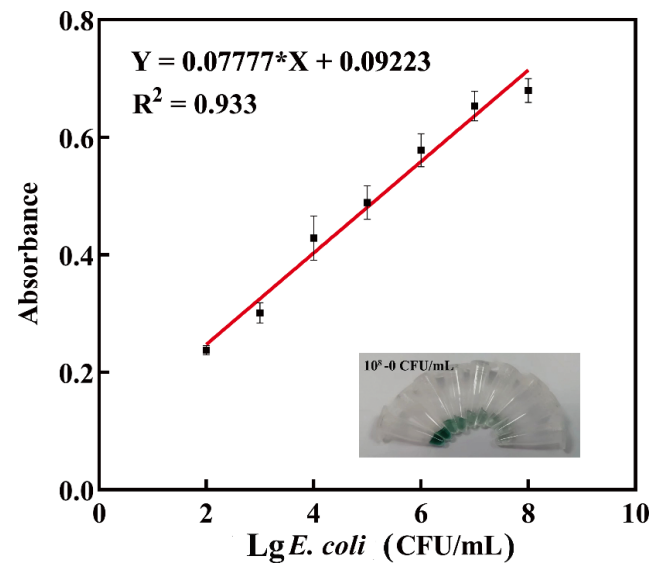

Fig. 5 The plot of the absorption intensity changes at $414 \mathrm{~nm}$ versus the logarithmic of the E. coli $\mathrm{O} 157: \mathrm{H} 7$ concentrations from $10^{2}$ to $10^{7} \mathrm{CFU} / \mathrm{mL}$.

Table 1 Performance comparisons of different methods for E. coli $\mathrm{O} 157: \mathrm{H} 7$ detection

\begin{tabular}{lccc}
\hline Technique & $\begin{array}{c}\text { Linear range/ } \\
\text { CFU mL }\end{array}$ & $\begin{array}{c}\text { LOD/ } \\
\text { CFU mL }^{-1}\end{array}$ & Reference \\
\hline $\begin{array}{l}\text { Chemiluminescence } \\
\text { immunoassay }\end{array}$ & $4.3 \times 10^{3}-4.3 \times 10^{5}$ & $1.2 \times 10^{3}$ & 26 \\
$\begin{array}{l}\text { Electrochemical } \\
\text { biosensor }\end{array}$ & $10-10^{7}$ & $10^{2}$ & 27 \\
$\begin{array}{l}\text { Graphene-interfaced } \\
\text { electrical biosensor }\end{array}$ & $10-10^{6}$ & $10-10^{2}$ & 28 \\
$\begin{array}{l}\text { Phagomagnetic } \\
\text { separation with }\end{array}$ & $10^{5}-10^{7}$ & $4.9 \times 10^{4}$ & 29 \\
enzymatic & & & \\
colorimetry & & & \\
$\begin{array}{l}\text { Impedance biosensor } \\
\text { Immunofiltration strip }\end{array}$ & $10^{3}-10^{8}$ & $10^{3}$ & 30 \\
This method & $10^{2}-10^{7}$ & $10^{4}$ & 31 \\
\hline
\end{tabular}

different densities of E. coli $\mathrm{O} 157: \mathrm{H} 7$, ranging from $10^{2}$ to $10^{8} \mathrm{CFU} / \mathrm{mL}$, were tested for sensitivity under optimized experimental conditions. As observed (Fig. 5), the colorimetric signal increased with increasing E. coli O157:H7 densities. A linear correlation between the absorbance at $414 \mathrm{~nm}$ and E. coli $\mathrm{O} 157: \mathrm{H} 7$ concentrations was calculated within the range of $10^{2}$ to $10^{8} \mathrm{CFU} / \mathrm{mL}$ (Fig. 5 inset). The linear regression equation was: $y=0.07777 X+0.09223 \quad\left(R^{2}=0.9813\right)$. According to these results, the effective limit of detection (LOD) for the colorimetric biosensor was $8.5 \times 10 \mathrm{CFU} / \mathrm{mL}$ at a signal to noise ratio of 3 standard deviation (where standard deviation is the standard deviation of the blank sample, $n=8$ ). Figure S1 (Supporting Information) displays the successful forming of the sandwich complex $\left(\mathrm{Fe}_{3} \mathrm{O}_{4} @ \mathrm{Ab}-E\right.$. coli O157:H7-hemin@MI). The LOD of the biosensor was lower than other E. coli $\mathrm{O} 157: \mathrm{H} 7$ detection methods, e.g., chemiluminescence immunoassay, ${ }^{26}$ electrochemical biosensor, ${ }^{27}$ graphene-interfaced electrical biosensor, ${ }^{28}$ hagomagnetic separation with enzymatic colorimetry, ${ }^{29}$ impedance biosensor, ${ }^{30}$ and immunofiltration strips $^{31}$ (Table 1).

\section{Specificity}

The specificity of the colorimetric immunosensor was analyzed. As shown in Fig. 6, none of the bacteria, except for

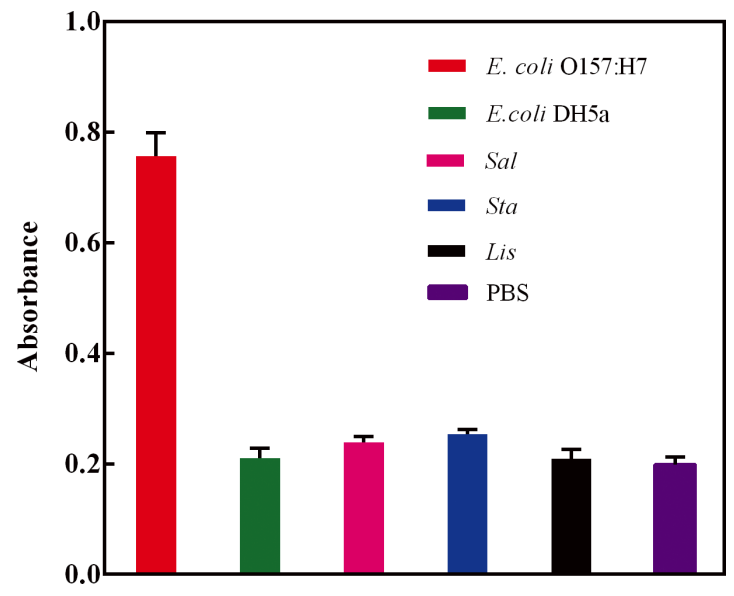

Fig. 6 Specificity assay for different pathogenic strains. The density of pathogenic bacteria was $1 \times 10^{8} \mathrm{CFU} / \mathrm{mL}$. The error bars represent standard deviations from three measurements.

Table 2 Recoveries of E. coli O157:H7 spiked in real sample

\begin{tabular}{cccc}
\hline $\begin{array}{c}\text { Original } \\
\text { value/ }\end{array}$ & $\begin{array}{c}\text { E. coli } \mathrm{O} 157: \mathrm{H7} 7 \\
\text { added/CFU mL }\end{array}$ & $\begin{array}{c}\text { E. coli } \mathrm{O} 157: \mathrm{H} 7 \text { found } \\
\text { (mean } \pm \text { standard } \\
\text { deviation/CFU mL }\end{array}$ & $\begin{array}{c}\text { Recovery, } \\
\%\end{array}$ \\
\hline 0 & $1 \times 10^{3}$ & $(0.8313 \pm 0.0253) \times 10^{3}$ & $83.13 \pm 2.53$ \\
0 & $1 \times 10^{4}$ & $(0.9164 \pm 0.062) \times 10^{4}$ & $91.64 \pm 6.2$ \\
0 & $1 \times 10^{5}$ & $(0.9465 \pm 0.045) \times 10^{5}$ & $94.65 \pm 4.5$ \\
\hline
\end{tabular}

E. coli $\mathrm{O} 157: \mathrm{H} 7$, generated relevant signals. These results showed that the method had good specificity for E. coli O157:H7.

The detection of spiked E. coli O157:H7 in milk

The practical applicability of this approach was ascertained by studying different densities of $E$. coli O157:H7 spiked into milk. From Table 2, E. coli O157:H7 spiked into milk (different densities at $10^{3}, 10^{4}$, and $10^{5} \mathrm{CFU} / \mathrm{mL}$ ) was analyzed for recovery. The recoveries ranged from 83 to $94 \%$, which met acceptable criteria for the validation of biological analysis methods, demonstrating the practicability of the colorimetric immunosensor for E. coli $\mathrm{O} 157: \mathrm{H} 7$ detection in real biological samples. ${ }^{31}$ Our results demonstrate that our colorimetric immunosensor provides excellent potential for the detection of E. coli $\mathrm{O} 157: \mathrm{H} 7$ in milk.

\section{Conclusions}

We successfully developed hemin@MI nanozyme composites with peroxidase activity, mimicking nanozymes as signal probes, and $\mathrm{Fe}_{3} \mathrm{O}_{4} @ \mathrm{Ab}$ magnetic nanocomposites as capture probes for the colorimetric immunosensor detection of pathogenic E. coli O157:H7. The colorimetric immunosensor can accurately test for $E$. coli $\mathrm{O} 157: \mathrm{H} 7$. The detection range for this pathogen was $10^{2}$ to $10^{8} \mathrm{CFU} / \mathrm{mL}$ with a LOD of $8.5 \times$ $10 \mathrm{CFU} / \mathrm{mL}$. More importantly, the simple, convenient and low cost colorimetric immunosensor provides a promising tool for the point-of-care detection of pathogenic bacteria, especially in underdeveloped regions. 


\section{Acknowledgements}

This work was financially supported by the National Key Research and Development Program of China (No. 2016YFD0501001).

\section{Conflict of Interest}

The authors declare that there is no conflict of interest.

\section{Supporting Information}

This material is available free of charge on the Web at http:// www.jsac.or.jp/analsci/.

\section{References}

1. S. M. Chekabab, J. Paquin-Veillette, C. M. Dozois, and J. Harel, FEMS Microbiol. Lett., 2013, 341, 1.

2. A. K. Deisingh and M. Thompson, J. Appl. Microbiol., 2004, 96, 419.

3. L. P. Godambe, J. Bandekar, and R. Shashidhar, 3 Biotech, 2017, 7, 130 .

4. S. Alamer, S. Eissa, R. Chinnappan, and M. Zourob, Mikrochim. Acta, 2018, 185, 164.

5. G. A. Suaifan, S. Alhogail, and M. Zourob, Biosens. Bioelectron., 2017, 90, 230.

6. J. Sun, J. Ge, W. Liu, M. Lan, H. Zhang, P. Wang, Y. Wang, and Z. Niu, Nanoscale, 2014, 6, 255.

7. J. Wu, X. Wang, Q. Wang, Z. Lou, S. Li, Y. Zhu, L. Qin, and H. Wei, Chem. Soc. Rev., 2019, 48, 1004.

8. Y. Lin, J. Ren, and X. Qu, Acc. Chem. Res., 2014, 47, 1097.

9. M. Liang and X. Yan, Acc. Chem. Res., 2019, 52, 2190.

10. N. Lu, M. Zhang, L. Ding, J. Zheng, C. Zeng, Y. Wen, G. Liu, A. Aldalbahi, J. Shi, S. Song, X. Zuo, and L. Wang, Nanoscale, 2017, 9, 4508.

11. Z. Farka, V. Cunderlova, V. Horackova, M. Pastucha, Z. Mikusova, A. Hlavacek, and P. Skladal, Anal. Chem., 2018,
90, 2348 .

12. D. Jiang, D. Ni, Z. T. Rosenkrans, P. Huang, X. Yan, and W. Cai, Chem. Soc. Rev., 2019, 48, 3683.

13. C. Zhang, S. Zhang, Y. Jia, Y. Li, P. Wang, Q. Liu, Z. Xu, X. Li, and Y. Dong, Biosens. Bioelectron., 2019, 126, 785.

14. Y. Wang, R. L. Liu, G. N. Chen, L. Wang, P. Yu, H. Shu, K. Bashir, and Q. Fu, Mikrochim. Acta, 2019, 186, 446.

15. G. Zhang, Z. Liu, L. Fan, and Y. Guo, Mikrochim. Acta, 2018, 185, 159.

16. Y. Yang, H. Zhang, C. Huang, D. Yang, and N. Jia, Biosens. Bioelectron., 2017, 89, 461.

17. W. Wu, Q. Wang, J. Chen, L. Huang, H. Zhang, K. Rong, and S. Dong, Nanoscale, 2019, 11, 12603.

18. M. Hu, Y. Wang, J. Yang, Y. Sun, G. Xing, R. Deng, X. Hu, and G. Zhang, Biosens. Bioelectron., 2019, 142, 111554.

19. J. Ge, J. Lei, and R. N. Zare, Nat. Nanotechnol., 2012, 7, 428 .

20. J. Guo, Y. Wang, and M. Zhao, Sens. Actuators, B, 2019, 284,45

21. Q. Tang, L. Zhang, X. Tan, L. Jiao, Q. Wei, and H. Li, Biosens. Bioelectron., 2019, 133, 94.

22. K. Y. Wang, S. J. Bu, C. J. Ju, Y. Han, C. Y. Ma, W. S. Liu, Z. Y. Li, C. T. Li, and J. Y. Wan, Microchim. Acta, 2019, 186, 57

23. S. Bu, K. Wang, C. Ju, C. Wang, Z. Li, Z. Hao, M. Shen, and J. Wan, Food Control, 2019, 98, 399.

24. Z. Zhao, J. Zhang, M. Wang, Z. Wang, L. Wang, L. Ma, X. Huang, and Z. Li, RSC Adv., 2016, 6, 104265.

25. M. S. Mannoor, S. Zhang, A. J. Link, and M. C. McAlpine, Proc. Natl. Acad. Sci. U. S. A., 2010, 107, 19207.

26. Y. Zhang, C. Tan, R. Fei, X. Liu, Y. Zhou, J. Chen, H. Chen, R. Zhou, and Y. Hu, Anal. Chem., 2014, 86, 1115.

27. M. Xu, R. Wang, and Y. Li, Analyst, 2016, 141, 5441.

28. A. Pandey, Y. Gurbuz, V. Ozguz, J. H. Niazi, and A. Qureshi, Biosens. Bioelectron., 2017, 91, 225.

29. Y. Zhang, C. Yan, H. Yang, J. Yu, and H. Wei, Food Chem., 2017, 234, 332.

30. J. Wu, R. Wang, Y. Lu, M. Jia, J. Yan, and X. Bian, Anal. Chem., 2019, 91, 1027.

31. M. Jia, J. Liu, J. Zhang, and H. Zhang, Analyst, 2019, 144, 573. 